\section{6 \\ AGRICULTURE AND THE WORLD FOOD PROBLEM}

T his presidential address to Section M (Agriculture), Dr. G. Scott Robertson compares the present world food problem with that in 1798 when Malthus put forward his theory that populations tend to outrun their means of subsistence. The invention of machinery, the discovery of artificial fertilizers, the development of transport and colonization for a time made his views seem unduly pessimistic and out of date, but two world wars have brought up afresh the problem of attempting to provide adequate food for the peoples of the world.

The two chief factors responsible for the present situation are the rapid increase in the world's population (estimated at 20 million per annum) and the improved standard of living of that population. Fortunately, the prospects of finding a solution are more hopeful to-day than they were a hundred and fifty years ago, when hand labour and primitive tools set a limit to agricultural production, for by merely applying existing knowledge and making a fuller use of available resources, the world output could be doubled or trebled in a relatively short time. The Food and Agriculture Organisation is doing valuable work in pointing the way by which this can be done, and the only permanent solution seems to be in increasing production in each country. The require. ments of India and China, for example, are so vast that outside help would be inadequate even if it could be provided and the immense transport difficulties overcome.

Aid from the more advanced countries can best be given by helping the less developed ones to modernize their agriculture so that they can feed their own peoples. To do this, very large quantities of fertilizers will be required, and fertilizer manufacture must form a part of their industrialization. Even in Europe and America, much could be done to improve output. More attention to the growing and conservation of grass, for example, would increase milk and meat production and at the same time reduce the competition with the human population for cereals. Enormous economies in grain crops could also be achieved if the ravages of pests during storage were prevented; the knowledge exists and only the practical application of it is needed. The Council of the Food and Agriculture Organisation has already taken this matter up and recommended member countries to take immediate and concerted action in such matters.

Losses in the animal world from disease are estim. ated as even more serious than in the case of crops, and the necessity for preventing this wastage becomes the more vital as the standard of living rises not only in advanced countries but also in the more primitive.

Improved nutritional standards will inevitably mean changes, for agricultural produce will have to play a more important part in world trade than in the past, and the old conception of exchanging agricultural for industrial products gradually give place to an interchange of agricultural products. Restrictions, such as tariffs and quotas, will have to disappear, for no country should be forced into a form of agriculture unsuited to its soil and climatic conditions. The peoples of the world, in fact, will not be properly fed or any real prosperity achieved until there is both a greatly increased output and the fullest inter. change of the products of agriculture on a worldwide scale.
September II, 1948 Vol. 162

\section{THE CORRESPONDING SOCIETIES AND THE COMMUNITY}

THE president of the Conference of Delegates of Corresponding Societies, Prof. H. J. Fleure, deals in his address with the relationship between the corresponding societies and the community. Many such societies belong to and have opportunities to serve our cities and counties in the important and necessary effort to re-emphasize social life, which has been submerged by the crowds that have taken the place of traditional groups, crowds made up of atomized individuals. Rousseau, Hobbes and others have too often spoken as though human society were made by the coming-together of individuals, whereas it is in society, itself basically a heritage from pre-human phases, that human individuality has struggled towards expression. The group again and again has sought order through imposed uniformity ; the individual has, increasingly, rebelled and has immensely extended men's vision. We need only read anything written about man and the universe before Copernicus, Bruno, Galileo, Newton and Darwin to realize the importance of the newer ideal "We seek the truth" ; imposed uniformity may prevail for a short time, but it must fade; it closes the mind.

In the late eighteenth century steam-power and mass-production set society sailing on an uncharted sea and found it philosophers to justify or excuse exploitation under the theory of laisser-faire. The atomization of the individual, the submergence of society in the crowd, have been widespread with unfortunate consequences. The corresponding societies and the British Association, both pledged to the search for truth, can help one another and our communities towards rehabilitation. The local society can help and advise planners in their work of adjusting the environment and can bring wisdom from the past without, one hopes, imposing that as a dead weight on the future.

The Education Act, 1944, essigns 'secondary' status to many schools hitherto primary, and in these the education, for the less bookish, must be to a considerable extent visual. Members of local societies can help in the schools to spread knowledge of the locality, can guide school parties, promote local museums of folklife, publish books and booklets that will help teachers and pupils to understand their locality; and the British Association can help with advice on such work; it could also organise short conferences in many towns and cities which cannot quite manage the full annual conference, sending delegates specially chosen because of the help they can give. Contacts spread over a few days and extending into the field as well as the lecture room can be more vitalizing and have a more enduring effect than visits of a lecturer for one evening's meeting.

Co-operative research on land utilization, on interpretation of Domesday and other historical surveys, on local names and implements, land tenures and field systems can all be made to help rehabilitate social life. Much of this work can find expression not only in the transactions of local societies, but also in local museums made intelligible to the public, in improved education with partnership between the societies and the teachers and pupils, as well as in scientific contributions to a National Atlas of Britain, a new survey of land utilization and many other efforts of both planners and historical and scientific searchers. 